\title{
Antimicrobial Activity Exerted by Total Extracts of Germander
}

\author{
RAUL CHIOIBAS ${ }^{1 \#, ~ R A Z V A N ~ S U S A N " \#, ~ M O N I C A ~ S U S A N ², ~ O V I D I U ~ M E D E R L E ², ~ D E L I A ~ B E R C E A N U ~ V A D U V A ², ~}$ \\ MATILDA RADULESCU2*, MIRCEA BERCEANU ${ }^{3}$, CORINA DANCIU ${ }^{3}$, ZAKZAK KHALED ${ }^{3}$, GEORGE DRAGHICI ${ }^{3}$, DANIELA MARTI ${ }^{4}$ \\ ${ }^{1}$ CBS Medcom Clinic Hospital, 12 Popa Sapca, 300054, Timisoara, Romania \\ 2 Victor Babes, University of Medicine and Pharmacy, Faculty of Medicine, 2 Eftimie Murgu Sq., 300041, Timisoara, Romania \\ ${ }^{3}$ Victor Babes University of Medicine and Pharmacy, Faculty of Pharmacy, 2 Eftimie Murgu Sq., 300041, Timisoara, Romania \\ 4Western University Vasile Goldis Arad, 94 Revolutiei Blvd., 310025, Arad, Romania
}

\begin{abstract}
In the present research, ethanolic and methanolic extracts of Teucrium polium (germander) were studied regarding the content of biologically active substances - in particular polyphenols - antioxidant activity and antibacterial activity. The extracts have been found to be rich in polyphenolic compounds, kaempferol and epichatechin have been found to be present in the highestconcentrations. The antioxidantactivity evaluated by the method of capturing the free radicals with DPPH revealed values close to those produced by the ascorbic acid. Antimicrobial activity was evaluated by the diffusimetric method and S. aureus and E. coli microorganisms were found to be the most sensitive while $P$. aeruginosa and fungal species were not sensitive.
\end{abstract}

Keywords: germander, extracts, polyphenols, antioxidant, antimicrobial

Currently, there is an increased interest in the study of natural antioxidants because they have been shown to be capable of inhibiting biological degeneration and exerting through mechanisms still incompletely elucidated protective effects on the body [1,2)]. Herbs are rich in a number of secondary metabolites (for example, flavonoids, tannins, alkaloids, etc.) that are responsible for protection from external environmental factors, most of them toxic. A number of studies have described herbs as first-choice options for addressing infectious diseases, due to their availability, lack of side effects and low toxicity $[3,4]$. In order to evaluate the biologically active effect of the different plant extracts, a first preliminary step is used to study the different activities, such as: antioxidant, antimicrobial, cytotoxic (in healthy cells) activity to be able in the future to relate the benefits of the extracts from natural sources compared to the consumption of drugs $[5,6]$. Due to the increase in the resistance to therapy of a significant number of resistant microorganisms, an extensive research has been developed in order to find new compounds with antibacterial properties. Thus, a series of samples of natural origin such as: herbal extracts, volatile oils, groups of biologically active compounds from different chemical classes or even a single bioactive compound have significant antimicrobial properties. The simultaneous study of the antioxidant activity of the compounds that exert antimicrobial activity is essential because the chemical groups responsible for the antioxidant activity are closely related to the rest of the activities. Teucrium grows predominantly in the Mediterranean area but the plant can be found on four continents on a large scale - Asia, Australia, America, and Europe. Some of the species related to the genus are used in folk medicine to treat digestive problems, those related to high blood pressure, fever, some diseases caused by parasites. In addition, studies in the field have dealt with the evaluation of various biological activities, including antibacterial, anti-inflammatory, antioxidants, and others $[7,8]$.

The present study was conducted in order to obtain, to characterize and to study the total hydro-alcoholic extracts
(Ger Eand Ger M) of teucrium/germander leaves in terms of different tests, such as: total polyphenols, flavonoids and flavonols content, main polyphenols content, antioxidant activity and antimicrobial activity.

\section{Experimental part \\ Materials and methods}

Teucrium polium L. (germander) coming from spontaneous flora was collected in Tunisia in the summer of 2016. The specific botanical recognition of the herb was performed at the Department of Pharmaceutical Botany, from Victor Babes University of Medicine and Pharmacy (Timisoara, Romania) and the plant voucher number TP_007 is preserved at the Faculty Herbarium. The plant material was dried according to the protocol for the processing of medicinal plants and thereafter minced in order to be used for obtaining extracts.

The chemical reagents, solvents, and standard substances were acquired from different manufacturers and suppliers Sigma-Aldrich; Merck KGaA (Darmstadt, Germany), Chemical Company S.A. (Iasi, Romania) and Lach-Ner, Ltd. (Neratovice, Czech Republic).

Leaves of germander $(50 \mathrm{~g})$ were extracted with ethanol $70 \%$ for two days at room temperature away from light in order to obtain total ethanolic extract (Ger E) and with methanol $80 \%$ for two days at room temperature in order to obtain methanolic extract (Ger M). The mixtures were filtered, centrifuged, subjected to evaporation using a rotary evaporator under vacuum, and then lyophilized and stored in the freezer until were used in other analyses.

Total polyphenols, flavonoids, and flavonols were detected by the classical methods, namely: i) total phenols (TP) - Folin Ciocalteu method as presented in the literature [9], and ii) flavonoids/flavonols (TF/TFv) - aluminium colorimetric test [9]. Individual polyphenols identification was realized with a HPLC-MS system (Shimadzu, Japan) and the condition and the conditions of analysis and identification were used after the studies presented in the specialized literature [9].

Antioxidant activity was assessed by DPPH assay. Summarily, a well-known volume of extract was treated 
with two $\mathrm{mL}$ ethanol $50 \%$ and half $\mathrm{ml}$ of DPPH $1 \mathrm{mM}$ was added, then the value of absorbance was measured at 517 $\mathrm{nm}$. The value of antioxidant activity was expressed as a percentage and was calculated by using the formula from previous studies [10].

The antimicrobial activity of germander extracts was examined by disc-diffusion method agains gram-positive bacteria, gram-negative bacteria and fungi - $S$. aureus (ATCC 25923), E. coli (ATCC 25922), P. aeruginosa (ATCC 27853), S. flexneri (ATCC 12022), S. pyogenes (ATCC 19615), C. albicans (ATCC 10231) and C. parapsilosis (ATCC 22019). The reference strains were reconstituted in $10 \mathrm{ml}$ glucose broth and then seeded on Columbia agar $+5 \%$ sheep's blood and Sabouraud respectively with chloramphenicol for fungi, thermostated for 24 hours at $37^{\circ} \mathrm{C}$. The density of the inoculum, i.e. the number of bacteria in contact with the tested extracts is an important element and conditions the reproducibility of the results. According to the CLSI (Clinical and Laboratory Standards Institute) standard, a bacterial suspension in sterile physiological serum equivalent to $0.5 \mathrm{Mc}$ Farland $\left(10^{8} \mathrm{CFU}\right.$ $/ \mathrm{mL}$ ) is prepared. For the two Candida strains utilized in the present study the density of inoculum was 2 Mc Farland. As a culture medium, was used the Mueller-Hinton agar (bioMerieux) recommended by CLSI, an environment that has a nutritional value that allows the optimal development of a large variety of germs and does not contain inhibitors of the action of antimicrobial substances. The jelly concentration was 1.5-1.7\%, the $\mathrm{pH}$ 7.2-7.4 and the thickness of the medium layer in the $4 \mathrm{~mm}$ Petri dishes. For Candida strains was used Mueller-Hinton medium supplemented with methylene blue (Sanimed). The sterility control of the media consisted of incubating a plate from the lot used for $24 \mathrm{~h}$ at $37^{\circ} \mathrm{C}$ and sterile micro-tablets with a diameter of $6 \mathrm{~mm}$ from Whatman filter paper no. 1 were employed. Cultures were treated with Ger E and Ger M $(200 \mu \mathrm{g} / \mathrm{disk})$ and antibiotic standards, gentamicin and nystatin discs, were used as positive control and hydroalcoholic mixture as negative control.

\section{Results and discussions}

The two germander extracts were tested in order to establish the chemical composition. Total phenols, flavonoids, and flavonols, determined by spectrophotometric methods are present in different amonts in both samples, as can be seen in Table 1 .

The concentration of different individual polyphenols was determined using HPLC-MS and is presented in Table 2. Kaempherol and epicathechin were the major compounds identified in the extracts, and other compunds, such as: acids - gallic, protocatechuic, caffeic, coumaric, ferullic and rosmarinic, resveratrol and quercetin were highlighted using this technique.

The antioxidant activity was assessed by a spectrophotometric method utilizing a molecule which possess a stable free radical - 2,2-Diphenyl-1-picrylhydrazyl able to change the solution color when accepts an electron from an antioxidant. The extract presents significant antioxidant activity almost comparable with the one of ascorbic acid, the positive control used in the present test (fig. 1).

Ascorbic acid
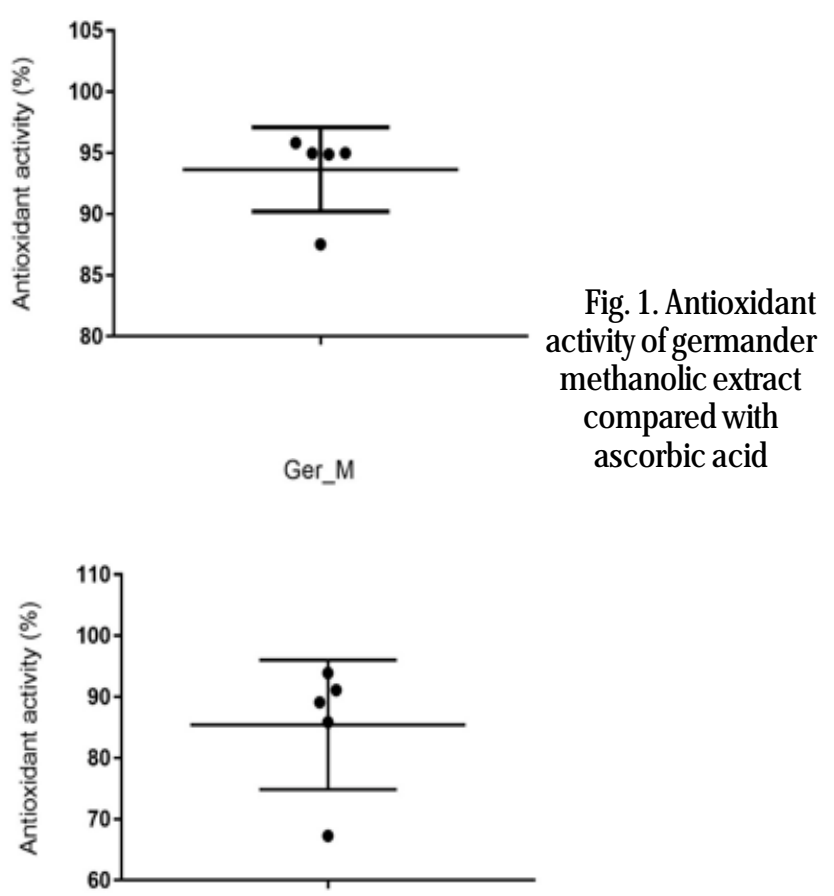

Table 1

TOTAL CONTENT OF POLYPHENOLS, FLAVONOIDSAND FLAVONOLSDETERMINED IN THE TWO EXTRACTSOF GERMANDER

\begin{tabular}{|c|c|c|}
\hline Compound & $\begin{array}{c}\text { Conc }(\mu g / g) \\
\text { Ger_E }\end{array}$ & $\begin{array}{c}\text { Conc. }(\mu g / g) \\
\text { Ger_M }\end{array}$ \\
\hline Gallic acid & 2.420 & 4.989 \\
\hline Protocatechuic acid & 0.763 & $3.069^{\circ}$ \\
\hline Caffeic acid & $7.636^{-}$ & 24.783 \\
\hline Epicathechin & 0 & 95.496 \\
\hline Coumaric acid & $\sigma^{-}$ & 5.914 \\
\hline Ferullic acid & $0.259^{-}$ & 1.932 \\
\hline Rutin & 0 & 0 \\
\hline Rosmarinic acid & $6.034^{-}$ & $88.953^{-}$ \\
\hline Resveratrol & 3.446 & $71.182^{-}$ \\
\hline Quercetin & 3.344 & $40.454^{-}$ \\
\hline Kaempherol & 17.776 & 1895.165 \\
\hline
\end{tabular}

Table 2

CONCENTRATION OF INDIVIDUAL POLYPHENOLSFROM GERMANDER EXTRACTS 


\begin{tabular}{|c|c|c|c|c|}
\hline Cultures & $\begin{array}{c}\text { Ger_E } \\
(\mathrm{iz}-\mathrm{mm})\end{array}$ & $\begin{array}{l}\text { Ger_M } \\
\text { (iz -mm) }\end{array}$ & $\begin{array}{l}\text { Antibiotic } \\
\text { (iz -mm) }\end{array}$ & $\begin{array}{l}\text { Solvent } \\
\text { (iz-mm) }\end{array}$ \\
\hline Staphylococcus aureus (+) & 20 & 22 & 16 & 6 \\
\hline Escherichia coli (-) & 16 & 19 & 12 & 6 \\
\hline Pseudomonas aeruginosa (-) & 6 & 6 & 16 & 6 \\
\hline Shigella flexneri (-) & 10 & 12 & 14 & 6 \\
\hline Streptococcus pyogenes $(+)$ & 7 & 8 & 22 & 6 \\
\hline Candida albicans & 6 & 8 & 11 & 6 \\
\hline Candida parapsilosis & 6 & 6 & 12 & 6 \\
\hline
\end{tabular}

Table 3

ANTIMICROBIAL ACTIVITY OF THE GERMANDER EXTRACTSOBTAINED BY DISK DIFFUSION METHOD.

DATA ARE PRESENTED ASDIAMETER (mm) OF IZINCLUDING THE VALUE $6 \mathrm{~mm}$ OF DISC DIAMETER
The in vitro antimicrobial activity of the ethanolic and methanolic germander extracts and the diameter of inhibition zones (iz) together with positive and negative controls are presented in Table 3.

Data highlighted that extracts influenced the growth of bacteria and fungi in a different manner. The inhibition zones have larger diameters than those of the antibiotics tested in the case of Staphylococcus aureus $(+)$ and Escherichia coli (-). As it can be observed in Table 3, Pseudomonas aeruginosa (-), Streptococcus pyogenes $(+)$, Candida albicans and Candida parapsilosis are resistant at the concentration tested.

In a study conducted to test the efficacy of volatile teucrium oil against gram positive and gram negative bacteria, $S$. aureus and $E$. coli were the most sensitive bacteria, and $P$. aeruginosa was resistant [11]. The effectiveness of volatile oil or teucrium extracts against $S$. aureus and $E$. coli, but not only, to a lesser extent, equal to or greater than standard antibiotics is described in several studies [12, 13]. Other researchers have studied the effect of Teucrium montbretii methanolic extract on different organisms and found that L. monocytogenes had the highest sensitivity and S. typhi the low est [14].

\section{Conclusions}

In the present study the preliminary evaluation of the chemical composition of two hydroalcoholic extracts, ethanolic and methanolic, of germander revealed the presence of polyhydroxylic compounds. The concentration of individual polyphenols was higher in the case of methanolic extract, and the majority compounds were found to be kaempferol and epicathechin. Both extracts showed antioxidant activity in comparison with that of ascorbic acid, a fact highlighted by the analysis with DPPH. Regarding antimicrobial activity an interesting data were recorded for Staphylococcus aureus (+) and Escherichia coli (-) while Pseudomonas aeruginosa (-), Streptococcus pyogenes (+), Candida albicans and Candida parapsilosis proved to be resistant at the tested concentrations. More detailed studies regarding in vitro and in vivo activities exerted by germander extracts are necessary to establish the relationship between the efficacy of the extracts and their safety for medical applications.

\section{References}

1. SHARIFIFAR, F., DEHGHN-NUDEH, G., MIRTAJALDINI, M. Food Chem. 112(4), 2009, p. 885.

2. ANDOR, B., DANCIU, C., ALEXA, E., ZUPKO, I., HOGEA, E., CIOCA, A., et al. Evid.-Based Complementary Altern. Med., 2016, Article Number: 7638542.

3. ZERROUG, M.M., ZOUAGHI, M., BOUMERFEG, S., BAGHIANI, A., NICKLIN, J., ARRAR, L. Adv. Environ. Biol. 5(2), 2011, p. 491.

4. CHEDIA, A., GHAZGHAZI, H., BRAHIM, H., ABDERRAZAK, M. Intl J Agron Plant Prod. 4(8), 2013, p. 1790.

5. CORLAN, I.V., CHEVERESAN, A., BERCEANU VADUVA, D., NICA, C., FAUR, A., RUMEL, R.C., POPOVICI, R.A. Rev. Chim.(Buchares), 69, no.10, 2018, p. 2891.

6. HORHAT, R.M., VLAICU, B., BAGIU, R., PUTNOKY, S., BAGIU, I., et al. Rev. Chim.(Bucharest), 69, no.6, 2018, p. 1371.

7. DJ ABOU, N., LORENZI, V., GUINOISEAU, E., ANDREANI, S., GIULIANI, M.C., DESJ OBERT, J.M., et al. Food Control. 30, 2013, p. 354.

8. GOULAS, V., GOMEZ-CARAVACA, A.M., EXARCHOU, V., GEROTHANASSIS, I.P., SEGURA-CARRETERO, A., FERNANDEZ GUTIERREZ, A. LWT - Food Sci. Technol. 46, 2012, p. 104.

9. POPOVICI, R.A., VADUVA, D., PINZARU, I., DEHELEAN, C.A., FARCAS, C.G., CORICOVAC, D., et al. Exp Ther Med. 18(2), 2019, p. 932.

10. CORINA, D., FLORINA, B., IULIA, P., CRISTINA, D., RITA, A., ALEXANDRA, P., et al. Curr Pharm Biotechnol. 18(13), 2017, p. 1067.

11. BELMEKKI, N., BENDIMERAD, N., BEKHECHI, C., FERNANDEZ, $X$. J. Med. Plants Res. 7(14), 2013, p. 897.

12. AKIN, M., OGUZ, D., SARACOGLU, H.T. Int. J. Appl. Pharm. Sci. 1, 2010, p. 55.

13. TOROGLU, S., DIGRAK, M., KOCABAS, Y.Z. Fen ve Muhendislik Dergisi 8(2), 2005, p.

14. OZKAN, G., KULEASAN, H., CELIK, S., GOKTURK, R.S., ÜNAL, 0. Food Control. 18(5), 2007, p. 509.

Manuscript received: 23.06.2019 